This report was prepared as an account of work sponsored by an agency of the United States Government. Neither the United States Government nor any agency thereof, nor any of their employees, makes any warranty, express or implied, or assumes any legal liability or responsibility for the accuracy, completeness, or usefulness of any information, apparatus, product, or process disclosed, or represents that its use would not infringe privately owned rights. Reference herein to any specific commercial product, process, or service by trade name, trademark, manufacturer, or otherwise does not necessarily constitute or imply its endorsement, recommendation, or favoring by the United States Government or any agency thereof. The views and opinions of authors expressed herein do not necessarily state or reflect those of the United States Government or any agency thereof.

\section{MLM-ML-82-42-0001}

\title{
1981 ANNUAL INDUSTRIAL SUMMARY OF FIRE AND PROPERTY DAMAGE EXPERIENCE
}

February 1982

$$
\begin{aligned}
& \text { THOCEDEO } \\
& \text { JIII } 01 \text { gegs } \\
& \text { i) STI }
\end{aligned}
$$

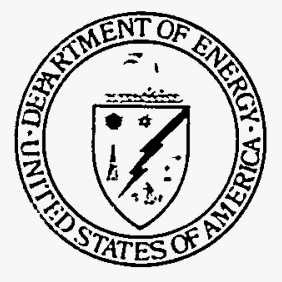

\section{MOUND FACILITY}

Miemisburg. Ohio 45342

operated by

Monsanto

\section{MONSANTO RESEARCH CORPORATION}

a subsidiary of Monsanto Company

for the

U. S. DEPARTMENT OF ENERGY

Contract No.DE-ACD4-76-DPOOO53 


\section{DISCLAIMER}

Portions of this document may be illegible in electronic image products. Images are produced from the best available original document. 


\title{
1981 ANNUAL INDUSTRIAL SUMMARY OF FIRE AND OTHER PROPERTY DAMAGE EXPERIENCE
}

\author{
U. S. DEPARTMENT OF ENERGY \\ DAYTON AREA OFFICE \\ MONSANTO RESEARCH CORPORATION \\ MRC-MOUND
}

This report summarizes the 1981 Calendar Year experience and activities of this. organization relative to the control of ALO property damage/losses from fire and other accident causes. 
I. INTRODUCTION AND OVERVIEW OF FIRE AND PROPERTY DAMAGE LOSSES FOR 198I

Nine fires were reported for the year with loss being held to $\$ 650.00$ on two minor vehicle fires.

A. Fire or Property Damage Loss Over $\$ 1000.00$

1. On March 6, 1981, a motor generator set failed and supplied low voltage power to an elevator motor causing it to burn up. Loss was $\$ 1981.00$.

2. On December 23, 1981, an employee, while exiting the plant-site, lost control due to a malfunction of a steering component on her vehicle and hit an electric pole. No injuries resulted, however, damages were listed at $\$ 1352.49 . *$

3. On September 9, 1981, an electrician made accidental contact with one phase of a 440-volt supply inside a substation. A breaker tripped out and power was shut off in HH Building. Continuous processes in HH Building were stopped. Losses of product were $\$ 4000$. Manhours to restart processes were $\$ 1000$.

B. 1981 Total Monetary Damage or Loss by Accident Type

IOSS IN. DOLLARS

\begin{tabular}{lcccr} 
Category & $\begin{array}{l}\text { Number of } \\
\text { Occurrences } \\
\text { Over } \$ 100 .\end{array}$ & Government & $\begin{array}{l}\text { Reim- } \\
\text { bursed } \\
\text { and Other }\end{array}$ & Total \\
\hline Electrical & 2 & 6981.00 & 0 & 6981.00 \\
Fire & 1 & 600.00 & 0 & 600.00 \\
Mechanical & 0 & 200.00 & 0 & 200.00 \\
$\begin{array}{l}\text { Radiation/ } \\
\text { Nuclear }\end{array}$ & 1. & 0 & 0 & 0 \\
Miscelianeous & 1 & $* 1352.49$ & 0 & 1352.49
\end{tabular}

*Anticipate full or partial reimbursement from individual's insurance company. 
Recurring Loss Prevention Costs are broken down into three categories with major deviations from 1980 explained. Total CY-1979 and CY-1980 are also shown as points of reference.

A. Salaries

1. Fire Protection Engineering

2. Fire control Personnel

3. Fire Brigade

Subtotal

B. Inspections

1. Outside contracts

2. Maintenance

Subtotal

C. Other Costs

1. Outside Contracts

Contract is for hydrostatic testing and recharging of high pressure cylinders such as $\mathrm{CO}_{2}$, breathing air, and HaIon

2. Training Materials

3. Equipment Replacement

Subtotal Total
1979

$\$ 25,500$

$\$ 282,000$

0

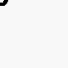

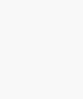

1981

1980

1981

Sub-Total

$\$ 27,500 \$ 28,000$

$\$ 329,500 \quad \$ 342,000$

900

0

$\$ 370,000$

$\begin{array}{llll}\$ 0 & \$ 0 & \$ 0 \\ \$ 2,000 & \$ 2,000 & \$ 2,500\end{array}$

$\$ 2,500$
$\$ 5,000$
$\$ 6,200$
$\$ 3,700$ 0

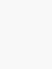


III. PROPERTY DAMAGE VULNERABILITY OF MRC-MOUND

A loss in excess of $\$ 1,000.000$ is considered to be not possible at Mound. 
IV. MAJOR FIRE PROTECTION ACCOMPLISHMENTS DURING CY-1981

A. Sprinkler protection was extended into the north dock of W-Building, and in Room 127A of DS Building. New buildings that were sprinklered include the Guard Post one addition, new plating facility, two modular office buildings, one trailer, and a solvent storage shed.

B. The GW-Building was totally renovated for Advanced Devices Production Control and Bonded Storage. The sprinkler protection was totally replaced and smoke detectors were installed in one area.

c. The carbon dioxide extinguishing system that was in the transformer vault in $\mathrm{T}-4$, has been replaced with a Halon-130l extinguishing system.

D. The expanded computer aided Design/Manufacturing Facility on the 3rd floor of OS-Building was provided with sprinkler and smoke detection systems.

E. Fire protection criteria was developed to protect a major new program area in T-Building.

F. The area of Rooms 125 and $125 \mathrm{~A}$ in DS-Building where flammable liquids were used in a fashion not meeting the necessary requirements of storage and ventilation, have now been upgraded by providing approved storage equipment and ventilation. This upgrading also resulted in a high standard of housekeeping.

G. A survey in the crawlspace of R-Building was performed and deficiencies such as openings in the fire partition, debris etc. were corrected.

H. A study was performed to evaluate the adequacy of the 6 " underground fire main that provides the water supply to the sprinkler systems in Buildings 27, 42 and the Energetic Materials Support Building (Building-67) presently under construction. Upgrading of the 6 " underground fire water main will occur when funding becomes available.

I. Fire Loss Audits were made on all new completed and occupied buildings with the remainder of the buildings being audited on schedule for the year 1981.

J. Approval was received and design work is in process for a long-awaited addition to the Central Fire station (Building 47). Due to an unexpected funding problem, the construction completion date of spring 1982 has been slipped to spring 1983. 
L. In addition to routine training, the fire department, emergency brigades and Electronics Department personnel were recertified in CardioPulmonary Resuscitation.

M. Design work has been completed, the bid let and installation of the new alarm system has begun.

N. Three new firefighters were hired to complete a newly formulated 320 hr. training program. Our program now meets the requirements for full certification by the State of Ohio. Upon completion of the training, the hirees were placed on laid-off status from the Firefighter Classification until the need arises for additional personnel.

O. A new program was started to replace the "Fire Hazard Reduction Inspection Program." Tours will be made of all MRC-Mound buildings at least annually. The tour group consists of the assigned Fire Protection Foreman, the assigned Safety Engineer and the Building Manager. The primary purpose of the tour is to identify safety and Fire Protection problems, either housekeeping or process in the building. Secondary purpose includes introducing a Building Safety or Fire Protection contact person and improving lines of communication. 
A. Complete an addition to the Central Fire Station to provide for operation of the Fire Control Group from one central location.

B. Complete the installation of the new computer based alarm system.

c. Provide timely and accurate fire protection engineering criteria and assistance to all process and construction projects including prompt response to all department fire protection requests.

D. Recertify all firefighters as Emergency Medical Technicians. 
VI. OBSERVATIONS, CONCLUS IONS AND RECOMMENDATIONS

A. The Fire Control Group responded to 232 requests for emergency response during 1981. This number is up slightly from 20.9 in 1980 .

B. The Fire Control apparatus was driven a total of 3800 miles and used 1,028 gallons of gasoline during drills, tests, and responding to the previously mentioned alarms.

c. The success of our Safety and Loss Prevention Program is due in large part to top management's commitments to loss prevention. A synopsis of some of the programs that contributed to this success is included for your review. (See Attachment I). 
MRC-MOUND

HOUSEKEEP ING, SAFETY, AND LOSS PREVENTION PROGRAMS

\section{EXECUTIVE SAFETY COMMITTEE}

This committee is composed of top plant management and is permanently chaired by the Director, MRC-Mound. The committee is responsible for providing plant direction on all health, safety and environmental protection matters. Annual results are established and their progress is reviewed on a monthly basis.

\section{HAZARDOUS CHEMICALS COMMITTEE}

This committee is chaired by the Industrial Hygienist and includes one representative from each of three departments; Engineering, Advanced Devices and Nuclear Operations. The representatives are appointed by their Department Director. Every area of the plant is audited routinely with emphasis given to Fire Protection Hazards (flammable liquids), Facility Safety and Industrial Hygiene. The audit is an awareness program with hazardous material information disseminated to operations people on a person-to-person basis and is followed up with recommendations made to improve Facility safety.

\section{FIRE LOSS AUDIT PROGRAM}

The Fire Loss Audit Program was reviewed and updated for all buildings scheduled during 1981. The frequency of the audits vary depending on value, programmatic impact and hazards of each building.

\section{SAFETY SUGGESTION PROGRAM}

This program allows employees to document safety concerns. The employee's supervisor is required to implement the suggestion within 10 days of receipt of the suggestion. The supervisor must keep the employee who made the suggestion advised if it is impossible to implement within 10 days. This program was developed as another tool for employee/supervisor communications to assure solution to safety concerns in a timely manner.

\section{LOSS PREVENTION AND ENVIRONMENTAL CONTROL (LP\&EC REVIEW PROGRAM)}

The purpose of this program is to coordinate the review of engineering projects and operating processes by Safety, Fire Protection, Health Physics, Industrial Hygiene, Criticality, Security, Environmental Protection, and Waste Management functions. This activity reviewed 38 conceptual designs, 25 internal Monsanto Research Corporation project designs and 16 DOE project reports. 


\section{SAFETY AND HOUSEKEEPING INSPECTION PROGRAM}

Maintenance of the high level housekeeping desired to reduce fire and property loss was achieved by the Safety and Housekeeping Inspection Program. In 1981 the program was developed to heighten management participation in the day-today safety effort at the Facility and increase visibility of top management in the work areas. The program provided for a minimum of three inspections annually of specified areas by inspection teams headed by Department Directors. Some modifications will be made to the Safety and Housekeeping Inspection Program in 1982 .

\section{SYSTEMS SAFETY}

The Systems Safety Program provides systematic safety reviews of facility and process designs for the purpose of identifying personnel or environmental risks associated with operations. These risks are documented in the form of Safety Analysis Reports or Safety Analysis Documents. This program also supports the LP\&EC Program in reducing risks through systems analysis while engineering design of facilities is underway. Techniques such as MORT and Fault Tree Analysis are commonly used within the Systems Safety Program.

\section{NUCLEAR CRITICALITY SAFETY COMMITTEE}

This group is responsible for administration of the Nuclear Criticality Safety Program for the Facility. The program insures the safe handling, storage and transportation of fissile materials. The committee reviews and approves procedures for fissile operations and periodically audits these functions to assure compliance. Furthermore, the committee also conducts training programs for personnel working with fissile material. The comittee provides technical guidance as required and is responsible for the Nuclear Criticality Procedures Manual MD 10038. The committee consists of two representatives from Nuclear Operations and one from Engineering and is chaired by the Nuclear Criticality Safety Engineer at Mound. 